\title{
Treatments for Temnocephalids Ectosymbiont Craspedella sp. on Cherax quadricarinatus and Cherax albertisii "Papua Freshwater Lobster"
}

\author{
Desy Sugiani, Angela Mariana Lusiastuti, Taukhid, Uni Purwaningsih \\ Research Institute for Freshwater Aquaculture, Ministry of Marine Affairs and Fisheries, Bogor, Indonesia \\ Email: desysugiani@yahoo.co.id
}

Received 9 November 2015; accepted 13 December 2015; published 17 December 2015

\begin{abstract}
There were two species of crayfish "red-claw" (Cherax quadricarinatus) and "blue-huna" (Cherax albertisii) for their aquaculture potential. Crayfish were susceptible to fungal (crawfish plague), parasitic (protozoa and nematodes), and bacterial pathogen. A number of ectosymbiont Craspedella sp. have been observed on red-claw and blue-huna. The flatworms were commonly found almost in the whole body, on the upper exoskeleton behind the head, in the gill cavity and on the claws and underside of crayfish. Although their number sometimes was very high, they didn't cause any problems especially for the new molting crayfish. Micro organisms living on the crayfish surface body and worms didn't cause any pathological changes. Adults Craspedella sp. can be eliminated by a short bath in salt water or formaldehyde $37 \%$ solutions for several hours. This treatment didn't kill worm eggs, so it needs to be repeated every one week. Moreover, hyposalinity or OST (Osmotic Shock Therapy) is one of the most effective therapies for ectoparasites on Craspedella sp. with dose of bath treatment 15 grams per litre of salt (15 ppt) for more than 3 hours, and dipped in salt water at $30 \mathrm{ppt}$ (or $3.0 \mathrm{ppm}$, seawater salinity) for 15 - 20 minutes.
\end{abstract}

\section{Keywords}

Craspedella sp., Cherax quadricarinatus, Cherax albertisii, Treatment

\section{Introduction}

Red claws have been grown successfully in ponds on a research scale for the last four years. In addition, many private companies have been aggressively engaged in the development of red claw production in Indonesia and abroad for several years. Kurniasih (2008) [1] has evaluated growth performance of freshwater cryfish by Chironomus sp. and artificial feed in Irian (C. albertisii) and Australian (C. quadricarinatus). The red claw may reach a total length of about $250 \mathrm{~mm}$ and weigh up to 600 grams. This is a non-burrowing species that is tolerant of a wide variety of habitats. Found in tropical regions throughout the world, including its native range of 
Northern Australia and Papua New Guinea, as well as introductions in Jamaica, parts of South America, and Puerto Rico, the red claw thrives in temperatures between 15 and 30 degrees Celsius (U.S. Fish \& Wildlife Service, 2012) [2]. Cherax quadricarinatus can tolerate intensive culture conditions without affecting their growth and survival and has ability to maintain a low routine metabolic rate, is highly tolerant to limited dissolved oxygen conditions and thus uses energy efficently, cryfish survives in earthen ponds under ambient winter temperatures (Carreno-Leon et al., 2014; Karplus et al., 1998) [3] [4].

This species has been reported to be a carrier of a number of pathogens, including viruses, bacteria, fungi, protozoan and metazoan parasites (Austin et al., 2009) [5]. Diseases such as the European Crayfish Plague (Aphanomyces) have devastated European stocks and reached British native stocks in 1986. Australia is the only continent to be Crayfish Plague free. Porcelain disease (or White Tail disease) can also occur in the yabby, caused by a single celled microscopic animal, the microsporidian Thelophania. The disease can easily be detected in its late stages when the underside of the tail turns white and the walking legs often become rigid and splayed. It is invariably fatal and seems to be transmitted by cannibalism of dead or dying yabbies that have the disease. This disease is not harmful to humans, and is present in possibly $5 \%$ of natural crayfish populations. Temnocephalid flatworms are 1 to $110 \mathrm{~mm}$ long leech-like animals, and their eggs are laid on the soft under surfaces of the crayfish. These worms are not true parasites but commensals because they feed upon particles of food scattered in the water while the crayfish is eating. They are not actively harmful to the crayfish (Australian Blue Yabby Aquaculture, 2010) [6].

Craspedellas occur as a result of poor water quality. They may be considered as commensals, however, with stress, overcrowding, low oxygen levels, improper water parameters, changes in temperature or poor diet, the parasites can multiply and the crayfish may then develop signs of systemic disease. Most parasitic organisms are opportunistic and may be present all the time in the tank or on the crayfish in low numbers, and only cause diseases when the crayfish is stressed. The amount of fish present in a tank, $\mathrm{pH}$, lighting, the water temperature, type of filtration system and water chemistries all influences the health of the fish.

There are several options of drugs or chemicals placed in the water, they are commonly referred to as bath treatments. Drugs delivered orally are generally mixed in the food, and are meant to deliver systemic effects. Injections may be utilized in cases where small numbers of fish are involved. Bath treatments are the most variable, in that a specific concentration of the chemical is placed in the water for a specific length of time. As a rule, lower concentrations are used for longer periods of time, and vice versa.

This research is a case study on the identification of parasites Craspedella sp. on crayfish "red-claw" (Cherax quadricarinatus) and "blue-huna" (Cherax albertisii) and how to control them with the option to follow the rules of fish health management practices using OST (Osmotic Shock Therapy) and parasiticide.

\section{Materials and Methods}

\subsection{Experimental Specimens and Identification}

Specimens of ectosymbiont Craspedella were collected from the commercial rearing unit of redclaw Cherax quadricarinatus and blue-huna Cherax albertisii and were observed for 1) number of individual infestation and 2) experimentation on treatment. To obtain live Craspedella sp., gills and wet mount from whole body of crayfish were placed in a shallow glass vessel containing clean water for scanning microscopy examination.

For the identification of Craspedella a temnocephalid tubellarian of Foundations of Parasitology by Schmidt and Roberts were used. Craspedella sp. was collected from the commercial redclaw Cherax quadricarinatus and blue-huna Cherax albertisii in two crayfish rearing tanks from West Java, Banten, Jakarta, and Central Java [7].

\subsection{Study Design and Treatment Conditions}

This trial examined formaldehyde and hypo salinity treatment on crayfish after exposure to Craspedella sp.

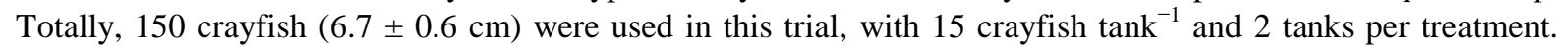
Success treatment was indicate signifcantly effects with all crayfish from each treatment has negative for Craspedella sp.

Parasite loads were evaluated base on severity level of infection, light $\left(<50\right.$ parasites fish $\left.^{-1}\right)$, medium (50 100 parasites fish $^{-1}$ ), and heavy infection ( $>100$ parasites fish $^{-1}$ ). The following treatments were conducted: 1 ) prolonged immersion with $0.1 \mathrm{~mL}$ formaldehyde per 10 liter water, 2) bath treatment with $0.2 \mathrm{~mL}$ formaldehyde 
per 10 liter water, 3) prolonged immersion used 3 ppt salt water, 4) bath treatment used 15 ppt salt water, 5) dipped in 30 ppt salt water, and 6) control.

\section{Result}

Craspedella was found on 120 crayfish (out of 150) in two crayfish rearing tanks when water temperature was varied from $24^{\circ} \mathrm{C}-32^{\circ} \mathrm{C}$. Craspedella sp. prevalence which observed on carapace, abdomen, walking legs, uropod, antennae, and antennulae of the crayfishwas 40\% - 60\% (Figure 1). Ultrastructural study of Craspedella sp. who attached to the gills showed that Craspedella sp. did not damage the gill epicuticle of crayfish (Figure 2). Therefore, it can be concluded that although Craspedella sp. did not have harmful effects on the respiration system of crayfish, they could have an adverse effect on their marketability.

The anatomy of Craspedella sp. a temnocephalid turbellarian showed in Figure 3. Temnocephalids are small and flattened, with tentacles at the anterior end and a weak. Adhesive sucker at the posterior end. They have leech-like movements, alternately attaching with the tentacles and posterior sucker. Rhabdites are located only at the anterior end, and mucous glands are mainly around the posterior sucker.

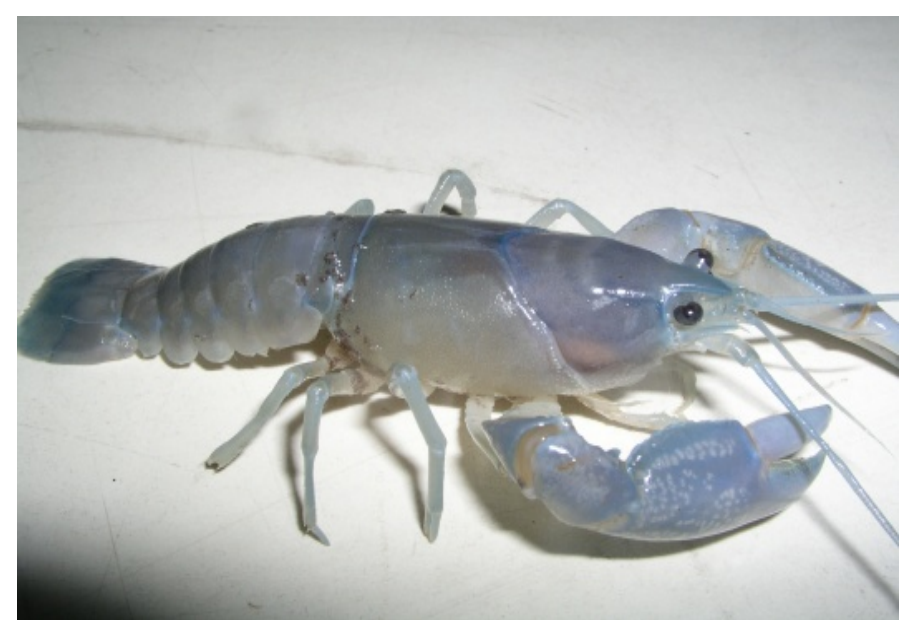

Figure 1. Craspedella sp. on the carapace and abdomen of red claw Cherax quadricarinatus.

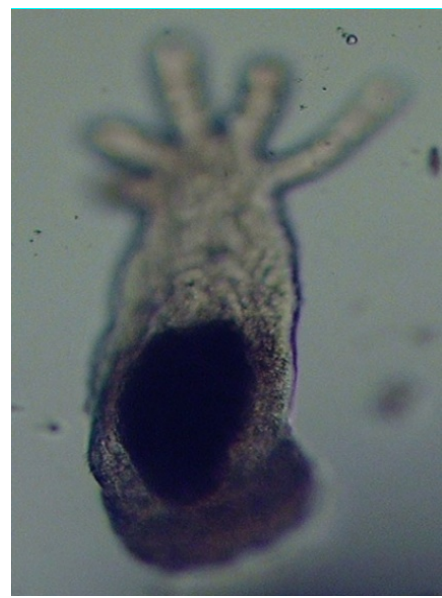

(a)

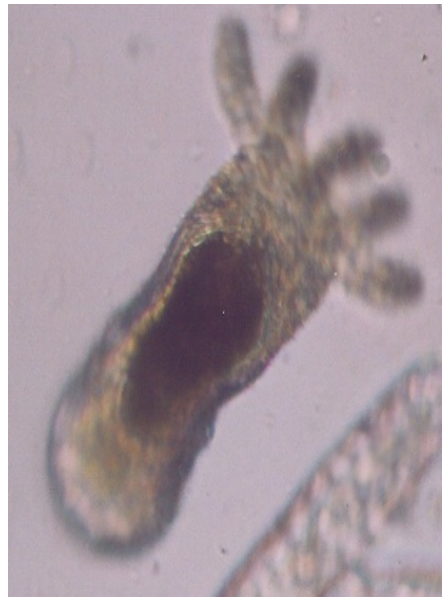

(b)

Figure 2. (a) microscopic view of Craspedella sp. from the carapace and abdomen of redclaw C. quadricarinatus; (b) microscopic view of Craspedella sp. from the gill of blue-huna C. albertisii Papua freshwater lobster. 
Crayfish "red-claw" (Cherax quadricarinatus) and "blue-huna" (Cherax albertisii) are susceptible to ectosymbiont Craspedella sp. These Craspedella sp. can be treated with bath treatment used 15 grams per 10 litre of salt (15 ppt) for up to 3 hours or it can be treated with short dipped (15 - 20 minutes) in 30 ppt per 10 litre of salt. Formaldehyde 37\% were used as a medicated treatments for Craspedella sp., using prolonged immersions for 24 hours, dosed at $0.1 \mathrm{~mL}$ per litre and bath treatments for 6 hours with $0.2 \mathrm{~mL}$ per litre of water (Table 1).

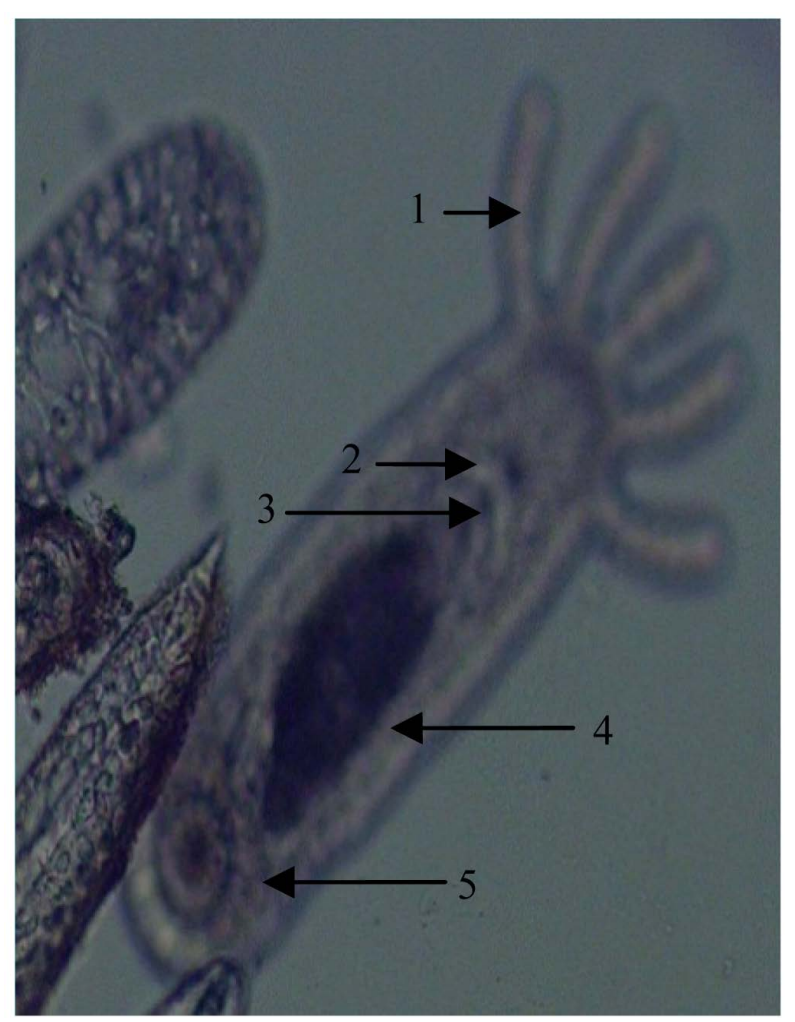

Figure 3. The anatomy of Craspedella sp. a temnocephalid turbellarian from C. albertisii. (1) tentacle, (2) excretory ampulla, (3) pharynx, (4) intestine, (5) papillate band succer.

Table 1. Evaluation of assay treatments in cryfish.

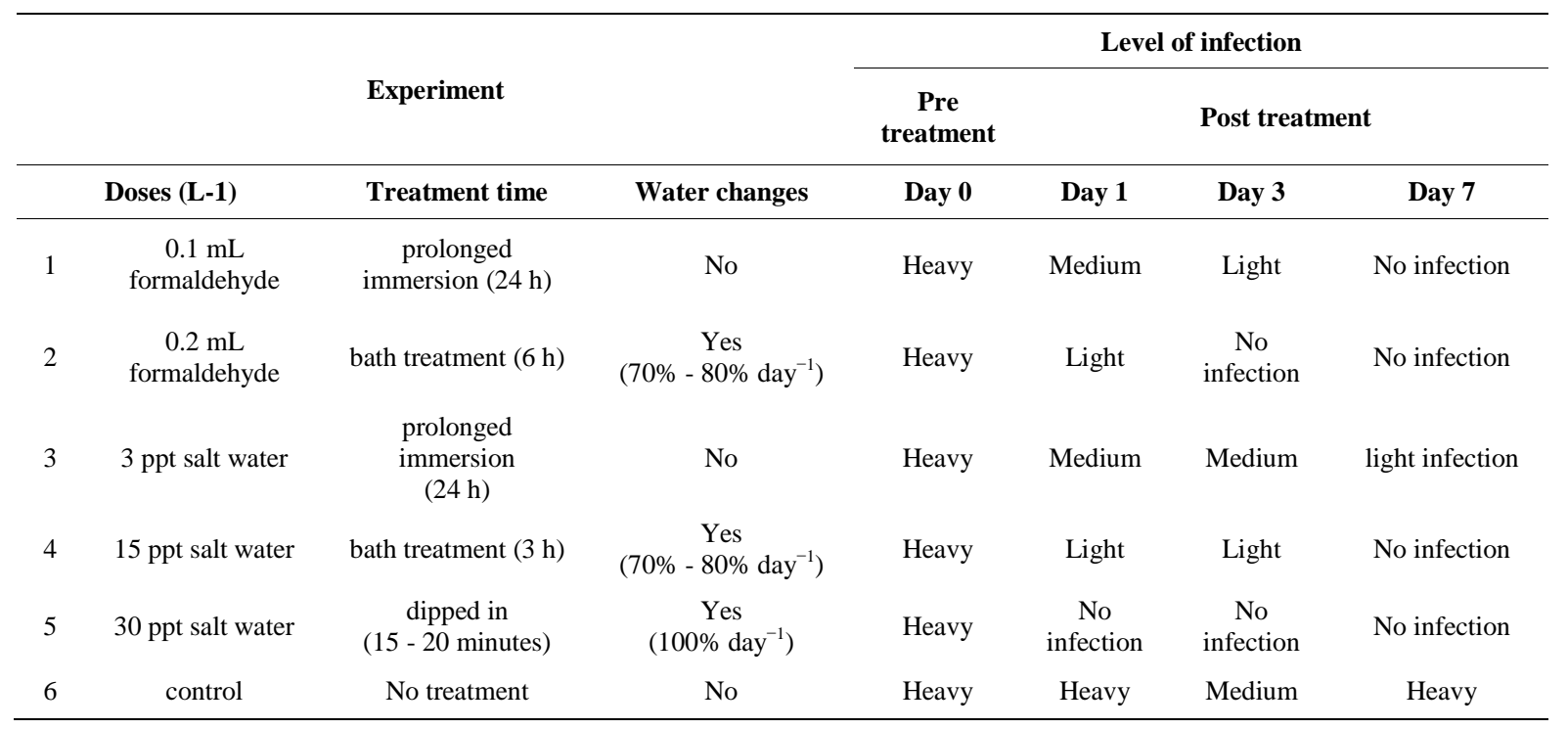




\section{Discussion}

Sewell \& Cannon (1995) [8] examined Craspedella sp. from the branchial chamber of redclaw cryfish, Cherax quadricarinatus from Queensland Australia. Rhabdites were observed to discharge from ducts opening mainly in small distal region of the ventral epidermis of the three central (of five) tentacles. The regions, devoid of ciliated sensory papilae, serve to adhere the anterior end of the worms during locomotion.

Craspedella spenceri (Haswell, 1893 [9]) is the only described species from the gills cavity of Cherax sp., the other undescribed species of Craspedella are known to live in the branchial chamber of crayfish. Rhabdites were found in discharge at open ducts mainly in a small distal region of the ventral epidermis of the three central (of five) tentacles (Hawking et al., 2006; Sewell \& Whittington, 1995) [10] [11].

Craspedella has a non-ciliated epidermis with nuclei located in the epidermis and with short microvilli. There is a thin basal lamina and thick underlying fibrous matrix. Rhabdites are secreted through ducts lined by microtubules. Multiciliate sense receptors consist of bundles of dendrites in a depression of the epidermis. Each dendrite has a cilium with a cross-striated rootlet; there are no electron-dense collars. Spermatozoa have peripheral microtubules which in cross-section are arranged in a ring-like or spiral fashion, numerous electrondense granules, mitochondria and a nucleus; axonemes of the $9+$ " 1 " type are free for most of their length. Centrioles occur in some nerve fibres. In Didymorchis parts of the epidermis are ciliated and epidermal perikarya are "insunk", connected to the surface part of the epidermis by a single cytoplasmic process. Epidermal cilia has cross-striated vertical and horizontal rootlets. In the ciliary tips a short electron-dense rod along the central pair of tubules extends to the tip, where it widens to become a terminal plate; peripheral doublets are gradually disappeared by losing their microtubules. Receptors observed are uniciliate. Spermatozoa are as in Craspedella. Ultrastructural evidence indicates that Craspedella and Didymorchis are closely related and belong to the Rhabdocoela (Rohde \& Watson, 1995; Rohde, 2005) [12] [13].

The five anterior tentacles and the single posterior attached to organ of the temnocephalan flatworm Craspedella sp. performed important roles in locomotion and attachment. Craspedella sp. moved using a low "looping" motion by alternately attaching the ventro-distal regions of the central three tentacles and the ventral surface of the posterior attachment organ. Temnocephalid flat worms are very mobile, moving with a leech-like looping motion over the surface of the host crustacean. Individuals are hermaphrodites and self fertilization may be possible, but cross fertilization is typical. Eggs are enclosed in a leathery capsule then attached to the surface of the host by a short stalk. Young temnocephalid flat worms hatch as miniature forms of the adults (Hawking et al., 2006; Hartenstein \& Hartenstein, 2001) [10] [14].

Temnocephalidae species are ectocommensal on freshwater crustaceans, crayfish in particular, so that they are always there on the host. They live attached to the outside body surface of the host or within the branchial chamber. The host crustacean is not harmed by the temnocephalid flat worm. Temnocephalid flat worms are predators feeding on small crustaceans, rotifers, insect larvae and nematodes. Prey is captured using tentacles. They may also be cannibalistic and at least one species, Craspedella spenceri, is primarily an algal feeder. Temnocephalidae species can live for long periods without food.

Formaldehyde 37\% was used as a medicated bath as a treatment for Craspedella sp., for 24 hours, and dosed at $1 \mathrm{~mL}$ per litre and $2 \mathrm{~mL}$ per litre of water. This is repeated for three treatments every day. Partial water changes (70\% - 80\%) should be performed between treatments. Formaldehyde added to inside fish tank; however, formaldehyde is toxic, it is preferable to use it in a treatment tank. This treatment is effective for removing Craspedella sp. from the whole body.

Jung et al. (2001) [15] describes a scientific relevant database suitable for determination of an appropriate withdrawal time and environmental risk assessment for therapeutic use of formaldehyde in the aquaculture industry of marine finfish. Formaldehyde concentrations in muscle were determined in cultured olive flounder (Paralichthys olivaceus) and black rockfish (Sebastes schlegeli) after bath treatment of formaldehyde $37 \%$ at 100, 300 and $500 \mathrm{mg} / \mathrm{L}$ for $1 \mathrm{~h}$. Loss of formaldehyde from aerated seawater by air blower and non-aerated seawater containing 25, 50, 100, 150 and $200 \mathrm{mg} / \mathrm{L}$ formaldehyde was also determined. Formaldehyde concentrations in the muscle of fish treated with $500 \mathrm{mg} / \mathrm{L}$ of formaldehyde for $1 \mathrm{~h}$ were significantly higher $(p-0.05)$ than the formaldehyde concentration control tissue when analyzed immediately after bath exposures 0 $\mathrm{h}$ withdrawal. However, there were no significant differences $(p-0.05)$ between formaldehyde concentrations in control tissue and tissue from fish sampled 24, 48 and $72 \mathrm{~h}$ after the exposure. Formaldehyde in seawater 
containing 25 - $200 \mathrm{mg} / \mathrm{L}$ formaldehyde reached detection limit concentration $0.05 \mathrm{mg} / \mathrm{mL}$ within 8 - 19 days, but its degradation was accelerated within 6 - 10 days by aeration.

Formaldehyde is an excellent parasiticide for use in aquariums, however, special care should be taken when using. Formaldehyde chemically removes oxygen from the water, thus supplying vigorous aeration with an air stone or power head and air diffuser during treatment is always recommended. Formaldehyde is a solution of 37\% formaldehyde gas dissolved in water. Formaldehyde is a potent germicide against parasitic organisms, and it has even shown certain properties to be considered an algaecide, fungicide, protozoacide and crustacide. Oxygen can eliminate formaldehyde from water, so it is important that the treated water should be well aerated. Formaldehyde is a carcinogenic so anyone who handling this chemical must be educated about its safety handling. Weekly treatments with formaldehyde $(25 \mathrm{mg} / \mathrm{L})$ are reasonable and likely to avert serious illness in many cases. Chemicals placed in the water are commonly referred to as "bath" treatments (Jung et al., 2001) [15].

Another treatment for Craspedella sp. should be dipped in salt water at $30 \mathrm{ppt}$ (3 ppm, seawater salinity) for up to several minutes, or until the fish rolls on its side and use tank water and dissolve 30 teaspoons of salt per gallon, then place the fish into this water, monitor it the entire time. After dipping, fish should be placed back in normal salinity water. This treatment repeated daily for three days, with a $30 \%-70 \%$ tank water change between treatments. This treatment is different from others, it is used to treat organisms in fish skin, and it's not for free-living stages in fish tank. Lower doses may be used as a continuous bath in fish tank. At dose 5 - 10 ppt (0.5 - $1.0 \mathrm{ppm}$ ), crayfish can survive for several hours to several days, and this will effectively kill the organisms. Diagnosis and treatment should be decide as soon as organisms founded, as prompt treatment is important to controlling this organism.

Interestingly, salt (sodium chloride), which is often ignored as a drugs and chemicals in fact is one safer and more effective method of treating Craspedella sp. and other external parasites than formaldehyde that are often thought to be better and more powerful. Salt is the best chemical to manage fish health. For most purposes, uniodized table salt is adequate, although it's justified to use aquarium salt specifically sold for that purpose, such as sea salt, solar salt, salt for livestock feed and Kosher salt. As an aid to osmoregulation, salt may be added in a concentration of $2-3$ ppt (or $0.02-0.03$ parts per million: ppm). This concentration is safe for freshwater fish, it's approximately one tenth the strength of seawater and protozoa cannot live on this concentration level. Prolonged immersion used 1 - 3 grams of salt per litre (1 - 3 ppt $-0.5 \%)$. The lower dosage is recommended for crayfish ponds as a prophylactic treatment over rainy seasons or on a permanent basis. A slightly higher dose of 5 grams per litre should be used for treating bacterial ulcers which appear as secunder infection of Craspedella. Adult red claws appear to be more tolerant of saline waters than juveniles, adult $C$. quadricarinatus responses to salinities ranged from 0 to $35 \mathrm{~g} \cdot \mathrm{L}^{-1}$ (Saoud \& Ghanawi, 2013) [16].

Hyposalinity or OST (Osmotic Shock Therapy) is one of the most effective, non-chemical ways to control parasitic diseases. We should learn all about how to effectively and safely use this treatment method, bath treatment uses 10 - 30 grams per litre of salt (10 - 30 ppt or 1\% - 3\%) for more than 30 minutes. The higher dose may only be tolerated for a few minutes. The selected dosage if needed a higher dose is 20 grams per litre for 20 minutes. Salt has long been used as a treatment in fish. Salt works well in some conditions, makes sure it is fully dissolved to prevent "salt burns", aerate water in short-term baths, remove fish if they "go over" as weaker ones may not stand the full treatment time, use cooking salt. It is safer than many pond treatments and will not have adversely affect. It is generally used at fairly high rates in short-term baths or dips, but it can be used as a longterm supportive treatment in ponds. Do not use salt containing anti-caking agents such as sodium ferrocyanide.

\section{Acknowledgements}

Authors are grateful to Prof. Dr. Suharsono, Indonesian Institute of Sciences, for providing the necessary lecture to carry out obove work.

\section{References}

[1] Kurniasih, T. (2008) Evaluasi pertumbuhan, sintasan, dan nisbah kelamin Huna Biru (Cherax albertisii) dan Red Claw (Cherax quadricarinatus) dengan pemberian pakan alami dan pakan buatan. Jurnal Ilmu-ilmu Perairan dan Perikanan Indonesia, 15, 61-68.

[2] U.S. Fish and Wildlife Service (2012) Australian Redclaw (Cherax quadricarinatus) Ecological Risk Screening Summary. Web Version. http://www.fws.gov/injuriouswildlife/pdf_files/Cherax_quadricarinatus_WEB_9-18-12.pdf 
[3] Carreno-Leon, D., Racotta-Dimitrov, I., Casillas-Hernández, R., Monge-Quevedo, A., Ocampo-Victoria, L., et al. (2014) Growth, Metabolic and Physiological Response of Juvenile Cheraxquadricarinatus Fed Different Available Nutritional Substrates. Journal Aquaculture Research Development, 5, 7. http://dx.doi.org/10.4172/2155-9546.1000220

[4] Karplus, I., Zoran, M., Milstein, A., Harpaz, S., Eran, Y., Joseph, D. and Sagi, A. (1998) Culture of the Australian Red-Claw Crayfish Cherax quadricarinatus in Israel. III. Survival in Earthen Ponds under Ambient Winter Temperatures. Aquaculture, 166, 259-267. http://dx.doi.org/10.1016/s0044-8486(98)00290-7

[5] Austin, C.M., Jones, C. and Wingfield, M. (2009) Cherax quadricarinatus. In: IUCN 2011, IUCN Red List of Threatened Species Version 2011.1. www.iucnredlist.org

[6] Australian Blue Yabby Aquaculture (2010) www.blueyabby.com

[7] Schmidt, G.D. and Roberts, L.S. (1977) Foundations of Parasitology. The C.V. Mosby Company, Saint Louis, 190195.

[8] Sewell, K.B. and Cannon, L.R.G. (1995) A Scanning Electron Microscope Study of Craspedella sp. from the Branchial Chamber of Redclaw Cryfish, Cherax quadricarinatus, from Queensland, Australia. Hydrobiologia, 305, 151-158. http://dx.doi.org/10.1007/BF00036378

[9] Haswell, W.A. (1893) A Monograph of the Temnocephaleae. In: Fletcher, J.J., Eds., Proceedings of the Linnean Society of New South Wales, Sydney, 93-152.

[10] Hawking, J.H., Smith, L.M. and Le Busque, K. (2006) Identification and Ecology of Australian Freshwater Invertebrates. http://www.mdfrc.org.au/bugguide

[11] Sewell, K.B. and Whittington, I.D. (1995) A Light Microscope Study of the Attachment Organs and Their Role in Locomotion of Craspedella sp. (Platyhelminthes: Rhabdocoela: Temnocephalidae), an Ectosymbiont from the Branchial Chamber of Cherax quadricarinatus (Crustacea: Parastacidae) in Queensland, Australia. Journal of Natural History, 29, 1121-1141. http://dx.doi.org/10.1080/00222939500770471

[12] Rohde, K. (2005) Ultrastructural Studies of Epidermis, Sense Receptors and Sperm of Craspedella sp. and Didymorchis sp. (Platyhelminthes, Rhabdocoela). Zoologica Scripta, 16, $289-295$. http://dx.doi.org/10.1111/j.1463-6409.1987.tb00075.x

[13] Rohde, K. and Watson, N.A. (1995) Comparative Ultrastructural Study of Posterior Succer of Four Species of Symbiotic Platyhelminthes, Themnocephala sp. (Themnocephalida), Udonella caligorum (Udonellidae), Anoplodiscus cirrusspiralis (Monogenea: Monopisthocotylea), and Philophthalmus sp. (Trematoda: Digenea). Folia Parasitologica, 42, 11-28.

[14] Hartenstein, Y.A. and Hartenstein, V. (2001) The Embryonic Development of the Temnocephalid Flatworms Craspedella pedum and Diceratocephala boschmai. Cell Tissue Res., 304, 295-310. http://www.pubfacts.com/detail/11396723/The-embryonic-development-of-the-temnocephalid-flatworms-Craspedellapedum-and-Diceratocephala-bosch

[15] Jung, S.H., Kim, J.W., Jeon, I.G. and Lee, Y.H. (2001) Formaldehyde Residues in Formaldehyde-Treated Olive Flounder (Paralichthys olivaceus), Black Rockfish (Sebastes schlegeli) , and Seawater. Aquaculture, 194, $253-262$. http://dx.doi.org/10.1016/S0044-8486(00)00530-5

[16] Saoud, I.P. and Ghanawi, J. (2013) A Review of the Culture and Diseases of Redclaw Crayfish Cherax quadricarinatus (Von Martens 1868). Journal of The World Aquaculture Society, 44, 29. http://dx.doi.org/10.1111/jwas.12011 